\title{
THE INDUSTRY COMPOSITION OF PRODUCTION AND THE DISTRIBUTION OF INCOME BY RACE AND ETHNICITY IN MIAMI
}

\author{
Robert David Cruz*
}

\begin{abstract}
This paper examines the empirical link between the growth of production in a central city and the distribution of income among its residents, by race and ethnicity, within an input-output modeling approach. The specific case of Miami, Florida is considered. This paper reviews the recent historical experience, which reveals considerable growth of employment in the central city at the same time that per capita income of city residents has declined. The decline in income has been particularly acute among black families. This discussion is followed by a presentation of the model and the estimation of model parameters. Income multipliers and their distributional effects are presented. The results show that in Miami, the present character of economic growth has few direct economic benefits for a large majority of the city's residents.
\end{abstract}

\section{EMPLOYMENT GROWTH AND INCOME DISTRIBUTION IN MIAMI}

Miami, in southeastern Florida, is the central city of the greater Miami metropolitan area. It encompasses approximately 28 square miles in an MSA that is nearly 332 square miles in total developed land area. The city represents the urban core of the metropolitan area: it remains the largest employment center; it is characterized by the highest residential densities and intensities of land uses; and it contains much of the metropolitan area's lower income housing. Approximately 21 percent of the MSA's population resides within the city's boundaries. Although Miami is a relatively young city (most of its growth occurred after World War II), economic and social trends over the past two decades have been similar in many ways to those trends witnessed in older U.S. cities. Despite a slight decline in official population estimates, the number of persons who work within the city's boundaries has grown steadily. The industry composition of employment, however, has changed significantly. An increasing proportion of those who work in the city live outside its boundaries and the city's housing stock has been steadily "filtering" down to lower income groups. Household income of city residents has declined sharply. Between 1979 and 1983, the median family income of city residents declined by 17 percent in real terms (Cruz 1989). ${ }^{1}$ The median family income of black residents, however, declined by 43 percent in real terms during this same short period. Median family income among Hispanics declined

\footnotetext{
*Assistant Professor of Economics, Florida International University, Miami, Florida.
} 
in real terms by 15 percent. The observed declines in income reflect changing residential patterns in the metropolitan area, with poorer families moving into city neighborhoods and more affluent families migrating to higher quality housing outside the city. The out-migration of black families to destinations with typically higher income, moreover, was particularly strong in the late 1970 s. $^{2}$ Similar patterns have been witnessed in other U.S. metropolitan areas (Kain 1968), (Mills and Price 1984), and (Kasarda 1985). Kasarda notes:

The transformation of older cities from centers of production and distribution of material goods to centers of information exchange and service consumption has profoundly altered the capacity of these cities to offer employment opportunities for disadvantaged residents. ([This result has been aggravated by]) ... the exodus of middle-income population and general retail and service establishments from much of the city beyond the central business districts (Kasarda 1985, 43).

Kain suggested that housing segregation limited black earnings because of higher commuting costs, which in turn discouraged employment, hindered labor market information, and created a higher incidence of discrimination as distance from black residential areas increased. Price and Mills (1985) provide empirical estimates of the negative effect of segregated housing on eamings of blacks, as this group may find housing only in the central city where job opportunities for their skill levels are relatively scarce.

In $1980,314,000$ persons worked within the city of Miami's boundaries. Only 28 percent of those employed in the city actually lived within the city's boundaries. Yet the city represented the place of employment for most of the city's black residents. This would be expected, given that poorer families are less likely to own private automobiles and the MSA's mass transit system provides relatively poor access to noncentral city employment centers. The city's Hispanic population also depended heavily on central city jobs. ${ }^{3}$

Between 1970 and 1980, the number of persons working within the city's boundaries increased by 66 percent. A large proportion ( 49 percent) of the growth was concentrated in executives, managers, professional, technical, and sales occupations. Yet few of the city's minority population were employed in such occupations in 1980. Approximately 18 percent of blacks who held jobs and lived within the city of Miami were employed in these occupations. By contrast, 27 percent of Hispanic workers and 52 percent of non-Hispanic white workers were employed in such occupations. ${ }^{4}$ The growth in employment by occupation is, of course, related to the growth of employment by industrial classification. The fastest growing industries during the 1970s were transportation, communica- 
tion and utilities, professional and related services, and wholesale and retail trade (Rodriguez 1987).

By 1980, dissatisfaction was quite evident among black residents because of their lack of participation in the city's economic expansion, and this alienation has been cited among the causes of civil disturbances in the 1980s (Porter and Dunn 1984). ${ }^{5}$ Although economic deprivation is not sufficient to explain civil disturbances (Lieberson and Silverman 1965), poverty, together with a perception of exclusion from the social system, has been a common element of race riots (Caplan and Paige 1968). While Porter and Dunn assert that Hispanic immigrants had taken jobs from black residents-and undoubtedly this was a widespread perception-no objective evidence of this conclusion has been put forward. Indeed, Table 1 reveals that significant gains in the number and proportion of blacks employed in higher paying "white-collar" jobs occurred between 1970 and 1980. Hence, the reasons for the lack of participation of blacks in the city's economic progress may lie more with occupational distribution than with a loss of jobs to immigrant groups. ${ }^{6}$ Despite the small gains in the occupational distribution of black residents, however, the distribution of income changed very little for black city residents during the 1970 s. In 1969 , the income accrued by blacks within the city represented 15 percent of all income, although blacks represent 23 percent of the population. By 1979, the income of black residents represented 18 percent of all city income, but blacks then represented 25 percent of the population. The economic status of blacks relative to Hispanics, however, did worsen. In 1969, Hispanics comprised 59 percent of the population and their income represented 41 percent of the city's total income. By 1979, Hispanics' share of income had increased to 50 percent, while their share of the population had declined to 56 percent (see Table 2).

Estimates of employment growth within the city's boundaries during the 1980s are difficult to ascertain, but several indicators suggest a continuation of the pattern established in the previous decade. While the pace of employment growth has most likely decelerated along with the growth of employment at the MSA level, white-collar employment has probably grown and blue-collar jobs most likely have declined. The stock of prime office space within the city's downtown increased by 40 percent between 1980 and 1987. ${ }^{7}$ Between 1979 and 1988, the City of Miami Planning Department estimates that the area of land used for commercial activity grew by nearly 200 acres (10.3 percent growth over 1979$)$, while industrial land uses fell by 205 acres (a 30 percent decrease over 1979). ${ }^{8}$ Commercial activity refers to retailing and office uses, while industrial land use refers to manufacturing and warehousing uses.

The number of workers in retail and wholesale trade activity within the city's boundaries grew by 9.4 and 3.1 percent, respectively, between 1982 and 1987. 
TABLE 1

Occupational Distribution of City of Miami Residents

\begin{tabular}{|c|c|c|c|c|c|c|}
\hline & \multicolumn{2}{|c|}{ Blacks } & \multicolumn{2}{|c|}{ Hispanics } & \multicolumn{2}{|c|}{ All Others } \\
\hline Occupation & Number & 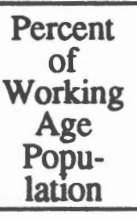 & Number & $\begin{array}{c}\text { Percent } \\
\text { of } \\
\text { Working } \\
\text { Age } \\
\text { Popu- } \\
\text { lation }\end{array}$ & Number & $\begin{array}{c}\text { Percent } \\
\text { of } \\
\text { Working } \\
\text { Age } \\
\text { Popu- } \\
\text { lation } \\
\end{array}$ \\
\hline \multicolumn{7}{|l|}{ 1980: } \\
\hline $\begin{array}{l}\text { Executives, admin. } \\
\text { and managers } \\
\text { Professional, technical }\end{array}$ & 1,082 & 2.34 & 7,662 & 7.12 & 4,895 & 14.48 \\
\hline and specialty & 3,140 & 6.79 & 7,888 & 7.33 & 6,487 & 19.18 \\
\hline $\begin{array}{l}\text { Sales } \\
\text { Clerical and administra }\end{array}$ & 2,046 & 4.43 & 9,971 & 9.27 & 4,061 & 12.01 \\
\hline $\begin{array}{l}\text { Clerical and aoministrative } \\
\text { support }\end{array}$ & 4,881 & 10.56 & 16,962 & 15.77 & 6,389 & 18.89 \\
\hline $\begin{array}{l}\text { Precísion production and } \\
\text { craftsman }\end{array}$ & 3,446 & 7.45 & 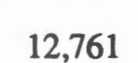 & 11.86 & 2,340 & \\
\hline $\begin{array}{l}\text { Operators and assemblers } \\
\text { Transport equipment }\end{array}$ & 3,440 & 7.44 & 14,646 & 13.62 & .469 & 1.39 \\
\hline $\begin{array}{l}\text { operators } \\
\text { Laborers }\end{array}$ & $\begin{array}{l}2,437 \\
3,364\end{array}$ & $\begin{array}{l}5.27 \\
7.28\end{array}$ & $\begin{array}{l}3,896 \\
4,950\end{array}$ & $\begin{array}{l}3.62 \\
4.60\end{array}$ & $\begin{array}{l}634 \\
362\end{array}$ & $\begin{array}{l}1.87 \\
1.07\end{array}$ \\
\hline $\begin{array}{l}\text { Private household } \\
\text { services } \\
\text { Other services } \\
\text { Farm workers } \\
\text { Total }\end{array}$ & $\begin{array}{r}1,821 \\
9,107 \\
741 \\
35,505\end{array}$ & $\begin{array}{r}3.94 \\
19.70 \\
1.60 \\
76.80\end{array}$ & $\begin{array}{r}615 \\
13,305 \\
1,117 \\
93,773\end{array}$ & $\begin{array}{r}0.57 \\
12.37 \\
1.04 \\
87.19\end{array}$ & $\begin{array}{r}75 \\
4,019 \\
205 \\
29,936\end{array}$ & $\begin{array}{r}0.22 \\
11.88 \\
0.61 \\
88.53\end{array}$ \\
\hline $\begin{array}{l}\text { Working age population } \\
\text { (not including enrolled in } \\
\text { high school or college) }\end{array}$ & 46,229 & & 107,554 & & 33,816 & \\
\hline \multicolumn{7}{|l|}{ 1970: } \\
\hline $\begin{array}{l}\text { Executives, admin. and } \\
\text { managers } \\
\text { Professional, technical and }\end{array}$ & 605 & 1.51 & 3,256 & 3.59 & 5,028 & 8.31 \\
\hline $\begin{array}{l}\text { specialty } \\
\text { Sales }\end{array}$ & $\begin{array}{r}1,900 \\
671\end{array}$ & $\begin{array}{l}4.73 \\
1.67\end{array}$ & $\begin{array}{l}4,956 \\
4,327\end{array}$ & $\begin{array}{l}5.47 \\
4.77\end{array}$ & $\begin{array}{l}7,924 \\
5,086\end{array}$ & $\begin{array}{r}13.09 \\
8.40\end{array}$ \\
\hline $\begin{array}{l}\text { Clerical and administrative } \\
\text { support }\end{array}$ & 3,441 & 8.57 & 11,100 & 12.24 & 12,862 & 21.25 \\
\hline $\begin{array}{l}\text { Precision production and } \\
\text { craftsman }\end{array}$ & 2,383 & 5.93 & 9,756 & 10.76 & 5,934 & 9.81 \\
\hline $\begin{array}{l}\text { Operators and assemblers } \\
\text { Transport equipment }\end{array}$ & 2,974 & 7.40 & 18,777 & 20.71 & 2,907 & 4.80 \\
\hline $\begin{array}{l}\text { Other services } \\
\text { Farm workers } \\
\text { Total }\end{array}$ & $\begin{array}{r}4,189 \\
7,193 \\
176 \\
30,281\end{array}$ & $\begin{array}{r}10.43 \\
17.91 \\
0.44 \\
75.40\end{array}$ & $\begin{array}{r}459 \\
11,117 \\
328 \\
69,941\end{array}$ & $\begin{array}{r}0.51 \\
12.26 \\
0.36 \\
77.13\end{array}$ & $\begin{array}{r}291 \\
6,521 \\
148 \\
49,213\end{array}$ & $\begin{array}{r}0.48 \\
10.78 \\
0.24 \\
81.33\end{array}$ \\
\hline $\begin{array}{l}\text { Working age population } \\
\text { (not including enrolled in } \\
\text { high school or college) }\end{array}$ & 40,163 & & 90,675 & & 60,513 & \\
\hline
\end{tabular}

Source: U.S. Department of Commerce, Bureau of the Census. Census Tracts: Miami, SMSA (1970 and 1980 volumes).

Note: "Working Age" population is defined as persons between the ages of 16 and 64. "Percent of working age" refers to percent of working age not enrolled in school. 
TABLE 2

Income Distribution of City of Miami Residents

\begin{tabular}{llcc}
\hline \hline Year & Race/Ethnicity & $\begin{array}{c}\text { Percent of } \\
\text { Income }\end{array}$ & $\begin{array}{c}\text { Percent of } \\
\text { Population }\end{array}$ \\
\hline & Blacks & 18 & \\
1979 & Hispanics & 50 & 25 \\
& All Others & 32 & 56 \\
1969 & Blacks & 15 & 19 \\
& Hispanics & 41 & 23 \\
& All Others & 44 & 59 \\
\hline
\end{tabular}

Source: U.S. Department of Commerce, Bureau of the Census.

Service-sector employment grew by 33 percent within this same period, with very large gains witnessed in hotel and lodging (93 percent), and engineering, accounting, management, et al (70 percent).

To the extent that income distribution across racial and ethnic groups is the result of the growth and composition of economic production, as well as changing residential patterns, the income trends observed during the 1970s are likely to have continued in the 1980s. The extended input-output model presented in the next section provides some empirical evidence on the link between income distribution and production.

\section{THE MODEL AND ITS CALIBRATION}

The model developed for the city of Miami consists of 31 productive activities or industries, eight labor occupations, and three household groups. The metropolitan region is separated into the urban "core" (i.e., the city of Miami) and the rest of the urban area (the Miami MSA). Each industry within the "core" faces demand for its output from both firms and households located within the core and from firms and households located outside the core. In order to produce output, local firms must purchase intermediate goods from other firms and hire labor and capital services. Payments for labor services are assumed to accrue to locally available labor, while profit-type income is assumed to be distributed to households outside the region. Some labor commutes to work from outside the urban core, and thus not all labor income accrues to city residents. The labor income that does accrue to city residents generates demand for locally produced goods and services. To a much lesser degree, the labor income accruing to non- 
city residents also results in demand for goods and services produced within the urban core. That is, workers who are employed in the city but who live outside its boundaries may consume some goods and services within the city. All prices and wage rates are taken as exogenously given and fixed.

Production in the model is characterized by an input-output structure. There are 31 industries identified in the model. The direct input coefficients were determined by regionalizing a national table of direct coefficients that had been updated to $1985 .^{9}$ The location quotient technique for regionalizing the direct coefficients was used (see Miller and Blair 1985, 296-99). A special tabulation of employment within the city was prepared by the U.S. Department of Commerce from County Business Patterns (unedited subcounty data). These employment figures, although unofficial estimates, were used to determine the location quotients for each of the 31 industries.

Labor income per unit of output was disaggregated among eight occupational categories. Labor compensation per unit of output by industry was determined from the national input-output table, and an employment by occupation and industry matrix for Florida was used to distribute per unit compensation to each occupation. ${ }^{10}$ Compensation per unit of output by occupational group was computed by: where

$$
u_{k j}=\left(e_{k j} / e_{j}\right) \bullet\left(w_{k} / \bar{w}\right) \bullet u_{j}
$$

$e_{k j}=$ the number of workers in occupational group "k"employed in industry "j";

$e_{j} \quad=$ total industry " $\mathrm{j}$ " employment;

$w_{k}=$ the median weekly earnings of occupational group "k";

$\bar{w}=$ the average of median earnings for all occupation groups; and

$u_{j} \quad=$ total labor compensation per unit of output for industry " $\mathrm{j}$ ".

Median weekly earnings were obtained from Current Wage Developments and refer to national wages. The ratio $w_{k} / \bar{w}$ is taken as a proxy for the ratio of average wages paid to a particular type of worker relative to the industrywide average wage.

From Journey to Work data we were able to estimate the proportion of laborers in each occupation who lived within the city's boundaries. Because only a fraction of workers in each occupation lived within the city, only a fraction of labor compensation from each industry accrues to city residents. Each unit of income accruing to labor of a specific occupational group was therefore distributed to city households according to the proportion of MSA workers (in 1980) belonging to that occupational group who resided within the city. Labor income to non- 
city residents was distributed according to the proportion of MSA workers residing in the remainder of the MSA. This practice treats workers as though they are homogeneous within the same occupation and as if they receive the same wage rate regardless of where they chose to live in the region. ${ }^{11}$

The average (and marginal) propensities to consume were determined in a two-step procedure. In the first step, the national propensities (based on the updated 1977 I-O table) were regionalized using the location quotient technique with national employment data as the reference point. In the second stage another set of location quotients was calculated using MSA employment levels as the reference point. In those cases where the location quotient with the MSA as the reference point was less than unity, a second adjustment was performed to allow for consumption purchases by city residents in the remainder of the MSA rather than from city firms. Accordingly, the consumption coefficients of city households, in those cases, were determined by:

$$
b_{i}=\left[\frac{\left(e_{i} / e\right)}{\left(e_{i}^{*} / e^{*}\right)}\right] \cdot\left[\frac{\left(e_{i} / e\right)}{\left(E_{i} / E\right)} \bullet B_{i}\right]
$$

where " $e_{i}$ " refers to industry employment within the city; the absence of the subscript refers to total employment; the superscript "*" refers to MSA employment; the uppercase " $E$ " refers to national employment; and $B_{i}$ is the national propensity to consume industry " $i$ " output.

To determine the propensity of noncity residents to consume goods and services from city firms, location quotients for the remainder of the MSA were calculated using MSA employment levels as the reference point. In those cases where these location quotients were less than unity, the propensities to spend on goods and services produced in the city were determined by:

$$
b_{i}^{r}=\left[1-\frac{\left(e_{i}^{r} / e^{r}\right)}{\left(e_{i}^{*} / e^{*}\right)}\right] \cdot\left[\frac{\left(e_{i}^{r} / e^{r}\right)}{\left(E_{i} / E\right)} \cdot B_{i}\right]
$$

The mathematical structure of the model, which is provided in an appendix, is linear and can easily be solved to yield the output and payroll multipliers.

Once the payroll multipliers by occupation have been calculated, the impacts can be disaggregated among the different racial/ethnic groups according to the representation of each racial/ethnic group in each occupational category. This practice implies that all workers within an occupational category receive the same wage regardless of their race or ethnicity, and, thus, the multipliers overestimate 
the impact on income for minority groups whenever wage discrimination is present.

\section{INCOME MULTIPLIERS AND INCOME DISTRIBUTION}

The payroll multipliers, disaggregated by race and ethnicity, for each of the 31 industries are presented in Table 3. Given the assumption that profit income accrues to nonresidents, the payroll multipliers represent the household income multipliers. The income multipliers are expressed as additional income per dollar of additional final sales in the respective industries. As one would expect, the income multipliers sum to less than unity, revealing the high degree of openness of such a small economy. The income multipliers for all household groups combined range from a low of 0.14 (for the Real Estate industry) to a high of 0.81 (for Other Financial industry).

The income multipliers also indicate considerable differences in the relative importance of various industries to the income of each social group. In a ranking of industries from highest income effect to lowest, only two industries (Textile and Apparel Manufacturing, and Other Transportation and Warehousing) appear among the top five for both blacks and Hispanics. Only one industry appears among the top five industries for both Hispanics and non-Hispanic whites, while blacks and non-Hispanic whites have no industries in common.

As a group, business and financial services and manufacturing (except for Textile and Apparel) rank relatively low in their impact on black income. Yet, it is only the growth of output in financial service industries that would lead to a decline in the relative income of blacks. In order for an increase in industry output to lead to a deterioration in the distribution of income for a given social group, the income multiplier for that group relative to the total income multiplier must be less than that social group's share of income. This difference between income (ie., payroll) multiplier share and 1970 income share is illustrated in Figure 1. The industries in Figure 1 are arranged by those with approximately the highest growth rates at the top to the slowest growing or declining industries at the bottom. All industries listed above Construction in Figure 1 grew at higher than average rates. The industries whose growth would be accompanied by a decline in the relative income of blacks are the Finance-Insurance and Real Estate group, Wholesale Trade, and Communications. Between 1970 and 1980, however, the industries that experienced the fastest growth rates were largely those whose growth adversely affected black income shares (see Table 4) or had no effect on their share of income. Indeed, within the last decade Miami has developed into a regional and international financial center. 
FIGURE 1

Output Growth and Distribution of Income

Share of multiplier less share of income

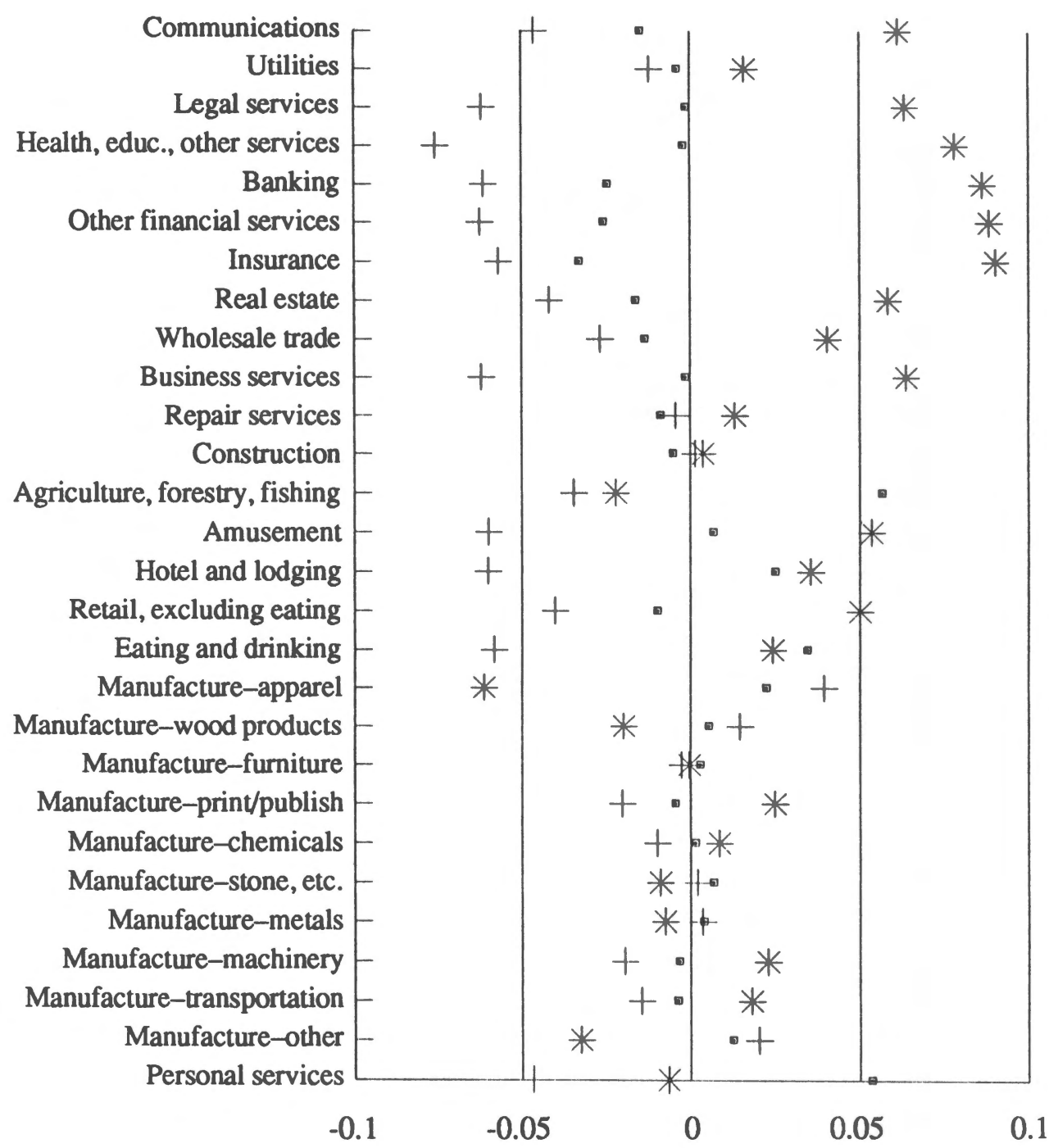

- Blacks

+ Hispanics

* All others 
TABLE 3

Income Multipliers By Race And Ethnicity

\begin{tabular}{|c|c|c|c|c|c|c|c|c|}
\hline \multirow{2}{*}{\multicolumn{2}{|c|}{ Industry }} & \multicolumn{2}{|c|}{ Blacks } & \multicolumn{2}{|c|}{ Hispanics } & \multicolumn{2}{|c|}{$\begin{array}{l}\text { Non-Hispanic } \\
\text { Whites }\end{array}$} & \multirow{2}{*}{$\begin{array}{c}\text { All } \\
\text { Households } \\
\text { Multiplier }\end{array}$} \\
\hline & & Multiplier & Rank & Multiplier & Rank & Multiplier & Rank & \\
\hline 1 & $\begin{array}{l}\text { Agricultural } \\
\text { services, forestry, } \\
\text { fishing }\end{array}$ & 0.1132 & 3 & 0.2059 & 22 & 0.2292 & 26 & 0.5483 \\
\hline 2 & Construction & 0.0926 & 13 & 0.2631 & 5 & 0.2838 & 11 & 0.6395 \\
\hline \multicolumn{9}{|c|}{ Manufacturing: } \\
\hline & $\begin{array}{l}\text { Food and kindred, } \\
\text { including tobacco }\end{array}$ & 0.0695 & 28 & 0.1837 & 27 & 0.1795 & 29 & 0.4328 \\
\hline 4 & Textile and apparel & 0.1196 & 1 & 0.3119 & 1 & 0.2627 & 18 & 0.6942 \\
\hline 5 & $\begin{array}{l}\text { Lumber, wood } \\
\text { products, } \\
\text { containers }\end{array}$ & 0.0781 & 24 & 0.2136 & 19 & 0.2115 & 27 & 0.5032 \\
\hline 6 & $\begin{array}{l}\text { Furniture and } \\
\text { fixtures }\end{array}$ & 0.0920 & 14 & 0.2455 & 9 & 0.2650 & 16 & 0.6026 \\
\hline & $\begin{array}{l}\text { Printing and } \\
\text { publishing }\end{array}$ & 0.0806 & 21 & 0.2164 & 18 & 0.2580 & 21 & 0.5550 \\
\hline 8 & $\begin{array}{l}\text { Chemicals, plastics, } \\
\text { drugs }\end{array}$ & 0.0894 & 17 & 0.2364 & 12 & 0.2650 & 17 & 0.5908 \\
\hline 9 & $\begin{array}{l}\text { Stone, clay, glass } \\
\text { products }\end{array}$ & 0.0853 & 19 & 0.2244 & 17 & 0.2347 & 25 & 0.5444 \\
\hline 10 & Fabricated metals & 0.0885 & 18 & 0.2382 & 11 & 0.2490 & 22 & 0.5757 \\
\hline & $\begin{array}{l}\text { Machinery, including } \\
\text { electrical }\end{array}$ & 0.0941 & 20 & 0.2504 & 8 & 0.2967 & 8 & 0.6412 \\
\hline 12 & $\begin{array}{l}\text { Transportation } \\
\text { equipment }\end{array}$ & 0.0853 & 12 & 0.2307 & 14 & 0.2672 & 14 & 0.5832 \\
\hline 13 & Other manufacturing & 0.1029 & 8 & 0.2726 & 4 & 0.2582 & 20 & 0.6337 \\
\hline & ransportation: & & & & & & & \\
\hline & $\begin{array}{l}\text { Local/suburb mass } \\
\text { transit }\end{array}$ & 0.0980 & 10 & 0.2517 & 7 & 0.2788 & 13 & 0.6285 \\
\hline & $\begin{array}{l}\text { Other transportation } \\
\text { and warehousing }\end{array}$ & 0.1081 & 5 & 0.2801 & 3 & 0.3067 & 7 & 0.6949 \\
\hline 16 & Communications & 0.0721 & 26 & 0.1938 & 26 & 0.2671 & 15 & 0.5329 \\
\hline 17 & Utilities & 0.0417 & 30 & 0.1137 & 30 & 0.1302 & 30 & 0.2855 \\
\hline 18 & Wholesale trade & 0.0806 & 22 & 0.2265 & 16 & 0.2839 & 10 & 0.5910 \\
\hline 19 & $\begin{array}{l}\text { Retail, excluding } \\
\text { eating and }\end{array}$ & & & & & & & \\
\hline & drinking & 0.0894 & 16 & 0.2362 & 13 & 0.3130 & 6 & 0.6387 \\
\hline 20 & Banking & 0.0757 & 25 & 0.2104 & 20 & 0.3178 & 5 & 0.6039 \\
\hline 21 & Other financial & 0.1015 & 9 & 0.2842 & 2 & 0.4320 & 1 & 0.8177 \\
\hline 22 & Insurance & 0.0797 & 23 & 0.2405 & 10 & 0.3611 & 3 & 0.6813 \\
\hline 23 & Real estate & 0.0189 & 31 & 0.0521 & 31 & 0.0705 & 31 & 0.1415 \\
\hline 24 & Hotel and lodging & & & & & & & \\
\hline & places & 0.1046 & 6 & 0.2093 & 21 & 0.2846 & 9 & 0.5984 \\
\hline 25 & Personal services & 0.1138 & 2 & 0.2033 & 23 & 0.2427 & 24 & 0.5598 \\
\hline 26 & Business services & 0.0967 & 11 & 0.2266 & 15 & 0.3281 & 4 & 0.6515 \\
\hline 27 & Legal services & 0.0720 & 27 & 0.1684 & 29 & 0.2437 & 23 & 0.4841 \\
\hline 28 & $\begin{array}{l}\text { Eating and drinking } \\
\text { establishments }\end{array}$ & 0.1042 & 7 & 0.1988 & 25 & 0.2626 & 19 & 0.5656 \\
\hline 29 & $\begin{array}{l}\text { Auto repair and } \\
\text { services }\end{array}$ & 0.0610 & 29 & 0.1756 & 28 & 0.1961 & 28 & 0.4327 \\
\hline 30 & $\begin{array}{l}\text { Amusement and } \\
\text { entertainment }\end{array}$ & 0.0898 & 15 & 0.2006 & 24 & 0.2829 & 12 & 0.5733 \\
\hline & $\begin{array}{l}\text { Health, education, } \\
\text { and other services }\end{array}$ & 0.1120 & 4 & 0.2532 & 6 & 0.3925 & 2 & 0.7578 \\
\hline
\end{tabular}


TABLE 4

Employment by Industry

\begin{tabular}{lrrr}
\hline \hline Industry & 1970 & 1980 & \% Change \\
\hline Construction & 9,455 & 20,168 & 113.3 \\
Manufacturing & 29,707 & 38,693 & 30.2 \\
$\begin{array}{l}\text { Transportation, } \\
\quad \text { communication, and }\end{array}$ & & & \\
$\quad$ public utilities & 13,076 & 49,435 & 278.1 \\
$\begin{array}{l}\text { Wholesale trade } \\
\text { Retail trade }\end{array}$ & 7,461 & 19,824 & 165.7 \\
Finance, insurance, and & 26,107 & 46,401 & 77.7 \\
$\quad$ real estate & 8,351 & 25,445 & 204.7 \\
$\begin{array}{l}\text { Business and repair } \\
\quad \text { Services }\end{array}$ & 6,592 & 16,850 & 155.6 \\
$\begin{array}{l}\text { Personal services } \\
\text { Professional and related }\end{array}$ & 18,869 & 12,011 & -36.3 \\
$\quad$ services & 21,225 & 59,601 & 180.8 \\
$\begin{array}{l}\text { Public administration } \\
\text { All other industries }\end{array}$ & 4,707 & 17,272 & 266.9 \\
Total employed, 16 years & 3,885 & 7,574 & 95.0 \\
$\quad$ & & & \\
$\quad$ and older & 149,435 & 313,274 & 109.6 \\
\hline
\end{tabular}

Source: U.S. Department of Commerce, Bureau of Census. Census Tracts: Miami (1970) Place of Work: Miami (1980).

The relative income of blacks has improved substantially by output growth in Agricultural Services, et al, Personal Services, Eating and Drinking Establishments, Hotel and Lodging, and Textile and Apparel Manufacturing. Manufacturing industries on the whole were either neutral or had a positive effect on blacks' share of income. During the 1970s, however, employment in Personal Services declined and employment in Retail Trade grew below the average rate. Manufacturing employment, moreover, expanded at a very slow pace. The remaining industries, which grew at above-average rates, are approximately neutral in their effect on the relative income of blacks.

One may also note from Figure 1 that the scatter diagram of points for blacks are more clustered around the zero axis than the points for Hispanics. That is, in general, the growth of output is likely to have less of an impact on black income shares than on Hispanic income shares. ${ }^{12}$ In addition, despite the larger income multipliers for Hispanics, fewer industries are likely to have a positive impact on Hispanic income shares than are likely to increase black income shares. As in the case of blacks, those industries that grew faster than average between 1970 and 1980 were industries whose growth coincides with a decline in Hispanics' share 
of income. The growth in the share of income earned by Hispanics during the 1970s therefore could be attributed to the increase in this group's labor force participation rate (Table 1) and to increases in Hispanic representation among higher skilled occupations.

We should also emphasize that the growth and composition of production has not been the only determinant of the actual changes in income shares that have occurred within the city. Changing residential patterns (especially the outmigration of more affluent blacks), no doubt has played a critical role in this phenomenon. The results of the model indicate the potential impact on income distribution when the residential patterns across racial groups and/or across income groups do not change and the extent to which the composition of production influences the distribution of income. The results also show how the growth of production may be of little significance to a large proportion of the city's population. Figure 1 illustrates that the fastest growing industries during the 1970s were the ones whose income effects were disproportionately concentrated among nonHispanic whites. Because relatively few non-Hispanic whites live in the city, most of the income effects accrue to nonresidents. ${ }^{13}$ These results are, of course, consistent with an increased feeling of economic alienation on the part of black residents.

\section{CONCLUSIONS}

Demographic trends in U.S. urban centers have resulted in the decline of average income in major cities and a worsening of income distribution. The growth and composition of output within urban centers has also contributed to the increasing disparity of income among racial and ethnic groups. In the preceding sections, we have illustrated the empirical link between output and income distribution by looking at the specific example of Miami. In the case of Miami, these structural changes in the urban economy have heightened social tensions to the point where confrontation between police and black residents have sometimes erupted into civil unrest. For this reason, much of the focus of this paper has been on the period between 1970 and 1980, but the conditions that contributed to the decline in the relative income position of blacks in the 1970s continued into the 1980s, and so did the incidences of civil disturbances. As 1990 census data becomes available, it will be interesting to see if increases in black labor force participation rates and representation of blacks in white-collar occupations were able to offset the negative distributional impacts of growth in financial service-type employment. It is clear that economic growth in its present form will not be able 
to improve the relative income position of black residents, and upward mobility among occupations is required to narrow the income gap.

While Hispanic incomes performed relatively well during the 1970s, several factors suggest that this trend may not have continued into the 1980s. Factors that contributed to the increase in the relative income of Hispanics-increases in labor force participation rates and representation in white-collar jobs-are not likely to have persisted in the 1980s. Labor force participation rates by 1980 had already reached levels near reasonable upper bounds, and the immigration of Hispanics during the 1980s, mainly from Mariel, Cuba, and Central America, included many semiskilled and unskilled laborers.

As these demographic and economic trends continue, the economic growth experienced within the city becomes less of an important factor in the determination of economic welfare among city residents. Local economic development initiatives that target the growth of office-type employment, moreover, become less significant to the objective of increasing the income of existing city residents.

\section{ACKNOWLEDGEMENTS}

I am very grateful to Robert Hessler for his valuable hours of research assistance in regionalizing the national I-O coefficients and debugging some of the software routines. Professor Maria Willumsen has provided me with her many insights into the problem of income distribution and economic development. Professor Antonio Jorge provided important comments and coordinated the research project with the city of Miami that served as the background for this study. I am also grateful for the suggestions of an anonymous referee. The author, of course, remains fully responsible for any shortcomings.

\section{ENDNOTES}

1. This data is from the Annual Housing Survey: 1983, Housing Characteristics for Selected Metropolitan Areas, U.S. Department of Commerce, Bureau of the Census. Median family income was computed as a weighted average of median income in renter-occupied and owner-occupied units. Except for black families, the decline in real income was due to inflation. The local CPI rose by 37 percent between 1979 and 1983.

2. Nearly 90 percent of blacks who migrated from the city to other areas within the MSA between 1975 and 1980 moved to areas with higher median incomes than the median income of blacks in the city. Sixty-two percent moved to 
areas where the median income was more than 50 percent higher than the median income at their place of origin. This may indicate that black families who could afford to move to higher-income neighborhoods were leaving the city. One may also note that nearly 50 percent of the MSA's black immigrants from abroad (mainly from the Caribbean) settled in the city of Miami between 1975 and 1980. A similar pattern of out-migration occurred among middle-income Hispanics as well.

3. The employment and occupational data for 1980 are from the Census of Population and Housing: 1980, U.S. Department of Commerce, Bureau of the Census. Fifty-three percent of all employed blacks living in the city of Miami had jobs located in the city. Fifty-eight percent of Hispanic workers who lived within the city had jobs within the city.

4. Figures for non-Hispanic whites are estimated as a residual by deducting blacks and Hispanics from totals. A relatively small number of other races are therefore included in such estimates. In 1980, less than 2 percent of the MSA's population belonged to these other races. Similarly, the proportion of Hispanics who are also classified as black represented 1.4 percent of the population in 1980.

5. The major riot of 1980 was followed by smaller, yet significant, disturbances in 1982 and 1989.

6. Only in the occupational group "laborers" and "private household services" did city blacks lose jobs, while city Hispanics gained employment. In the case of "operators and assemblers," blacks experienced absolute gains in the number of jobs, while Hispanics experienced absolute losses. The proportion of blacks between the ages of 16 and 64 who were employed declined between 1970 and 1980. But this decline in the labor force participation rate was due entirely to an increase in school enrollment rates. Porter and Dunn also suggest that the economic progress of blacks was thwarted by Hispanic entrepreneurs who were more successful in the competition for scarce economic development assistance funds.

7. City of Miami Planning Department estimates, based on real estate market data provided by Coldwell Banker. See Cruz (1989).

8. Because there was very little undeveloped land within the city in 1979 , nearly all of the growth in "commercial" land area represents a redistribution of land uses. See Barker, Hett and Roddy (1989, I-4).

9. The software package ADOTMATR produced by Resource, Economics and Management Analysis (Lincoln, Nebraska) was used to update the national 1977 I-O table to 1985 , to regionalize the national table, and to compute the type II multipliers.

10. The occupation by industry data for 1980 was obtained from the 1980 U.S. Census of Population and Housing subject report series. 
11. The marginal impacts we are attempting to estimate are therefore limited to those cases where discrimination is absent.

12. The distance between the points for Hispanics and the zero axis are greater than for blacks in Figure 1.

13. Non-Hispanic whites currently represent between 45 and 50 percent of the MSA population, but less than 25 percent of the city's population. Income multipliers for city and noncity residents were also calculated. The share of additional income accruing to city residents never exceeded 34 percent for any industry, and averaged 30 percent of the total payroll multiplier.

\section{APPENDIX}

The structure of the model may be represented by the following equations.

The structure of production and the supply/demand balance equations are given by:

$$
\begin{aligned}
x_{1} & =a_{11} x_{1}+a_{12} x_{2}+\ldots+a_{1 J} x_{J}+b_{1} y+b_{1}^{r} y^{r}+\bar{v}_{1} \\
& : \\
& \cdot \\
x_{J} & =a_{J 1} x_{1}+a_{J 2} x_{2}+\ldots+a_{J J} x_{J}+b_{J} y+b_{J}^{r} y^{r}+\bar{v}_{J}
\end{aligned}
$$

where " $x$ " refers to the value of output, the $a_{i j} s$ are the regionalized direct input coefficients, the $b$ 's represent the propensities to consume, " $y$ " is the income of city residents, $y^{r}$ is the income of residents in the remainder of the MSA, and $\bar{v}$ represents exogenous demand. Note that prices are fixed and set to unity (the $x$ ' $s$ are both quantity and value of output).

Labor income accruing to each occupational group is given by:

$$
\begin{aligned}
w_{1} & =u_{11} x_{1}+u_{12} x_{2}+\ldots+u_{1} x_{J} \\
& : \\
& : \\
w_{K} & : u_{K 1} x_{1}+u_{K 2} x_{2}+\ldots+u_{K J} x_{J}
\end{aligned}
$$

where $u_{k j}$ refers to compensation for labor of type "k" per unit of output of industry " $j . "$

The income of city residents is given by:

$$
y=d_{1} w_{1}+d_{2} w_{2}+\ldots+d_{K} w_{K}+\bar{y}
$$


where $d_{k}$ represents the proportion of workers of type " $k$ " that live within the city and $\bar{y}$ is household income that is independent of city production.

The income of noncity residents is given by:

$$
y^{r}=\left(1-d_{1}\right) w_{1}+\left(1-d_{2}\right) w_{2}+\ldots+\left(1-d_{K}\right) w_{K}+\bar{y}^{r} .
$$

We can express this system of equations as:

$$
\left[\begin{array}{l}
x \\
w \\
y
\end{array}\right]=\left[\begin{array}{lll}
a & o & b \\
u & o & o \\
o & \delta & o
\end{array}\right]\left[\begin{array}{l}
x \\
w \\
y
\end{array}\right]+\left[\begin{array}{l}
\bar{v} \\
o \\
\bar{y}
\end{array}\right]
$$

where $x, w$, and $y$ are column vectors corresponding to the $x_{j} s, w_{k} s$ and $\left[y, y^{r}\right]^{\prime}$, respectively. $a$ is the $31 \times 31$ matrix of regionalized direct input coefficients. $u$ is the $8 \times 31$ matrix of labor compensation per unit of output and $\delta$ is the $2 \times 8$ matrix of distribution parameters $d_{k}$ and $1-d_{k}$ b is a $31 \times 2$ matrix of marginal propensities to consume. $\bar{v}, \bar{y}$ are column vectors representing exogenous final demands and income, respectively. The zeros represent empty cells in the matrix. Letting the matrix equation above be written as $z=A z+v$, the matrix of multiplier impacts is the (expanded) Leontief inverse:

$$
\left[\frac{d z}{d v}\right]=[I-A]^{-1}
$$

\section{REFERENCES}

Barker, R., M. Hett, and A. Roddy. "Land Use Analysis." In Miami Comprehensive Neighborhood Plan: Data and Analysis. City of Miami Planning Department, 1989.

Caplan, N., and J. Paige. "A Study of Ghetto Rioters." Scientific American 219 (1968): 15-21.

Cruz, R. "Economic Profile." In Miami Comprehensive Neighborhood Plan: Data and Analysis. City of Miami Planning Department, 1989.

Kain, J. "Segregation, Negro Employment and Metropolitan Decentralization." Quarterly Journal of Economics 84 (1968): 175-97.

Kasarda, John. "Urban Change and Minority Opportunities." In The New Urban Reality, ed. Paul E. Peterson. Washington, D.C.: The Brookings Institution, 1985.

Lieberson, S., and A. Silverman. "The Precipitants and Underlying Conditions of Race Riots." American Sociological Review 30 (1965): 887-98. 
Miller, R., and P. Blair. Input-Output Analysis: Foundations and Extensions. Englewood Cliffs, N.J.: Prentice-Hall, 1985.

Mills, E., and R. Price. "Metropolitan Suburbanization and Central City Problems." Journal of Urban Economics 15 (1984): 1-17.

Norton, R. D. "The Once and Present Urban Crisis." Urban Studies 24 (1987): 480-88.

Porter, B., and M. Dunn. The Miami Riot of 1980. Lexington, MA: Lexington Books, 1984.

Price, R., and E. Mills. "Race and Residence in Earnings Determination." Journal of Urban Economics 17 (1985): 1-18.

Rodriguez, E. "Changes in Population Characteristics and Job Opportunities: The Case of the City of Miami." Unpublished Masters Thesis, Florida International University, 1987.

U.S. Department of Commerce, Bureau of the Census. Census of Population and Housing: 1970 Census Tracts. Miami, FL, SMSA.

. Census of Population and Housing: 1980 Census Tracts. Miami, FL, SMSA.

. Journey to Work: 1980.

. Occupation by Industry: 1980.

U.S. Department of Labor, Bureau of Labor Statistics. Current Wage Developments. 38, No. 3, March 1986.

. Current Housing Reports, H-170-83-28, Annual Housing Survey: 1983, Housing Characteristics for Selected Metropolitan Areas.

Willumsen, M. "The Impact of Production Structure on Income Distribution: A Multiplier Approach." Review of Regional Studies 20 (1990): 12-22. 